\title{
O MÁGICO ETERNO
}

HUMBERTO WERNECK

Mineiro de Belo Horizonte, jornalista, cronista, contista e escritor. Em 2006 e 2007 organizou a obra de Murilo

Reunião pela Companhia das Letras. Publicou, entre outros livros, $O$ desatino da rapaziada: jornalistas e escritores em Minas Gerais (1992), Pequenos fantasmas (2005), O santo sujo: a vida de Jayme Ovalle (2008), Esse inferno vai acabar (2011) e Sonhos rebobinados (2014).
Sei que 104 anos não é número redondo, desses que ensejam comemorações - mas, para mim, que diferença faz, se no caso se trata de Murilo Rubião que, desaparecido aos 75 , teria nesta segunda-feira chegado a essa idade? Não há 1 ㅇ de junho em que não me lembre dele de maneira especial, mais ainda que nos outros 364 dias do ano - e não estou falando apenas do escritor graúdo, do artista incorruptível que ele foi, mas também da pessoa - como poucas - decisiva em minha vida. Não, não exagero na verdade, não consigo imaginar como teriam as coisas se passado para mim se não tivesse, aos 21, topado com Murilo em meu caminho.

Foi em meados da década de 1960. Ao cabo de larga temporada em Madri, como adido comercial durante o governo JK, ele tinha voltado para Belo Horizonte, discretíssimo, sem alardes de europeu recente. Para mim e para alguns companheiros de geração, adolescentes com fumaças literárias, ele era um enigma. Podia até não existir.

Pelo menos não era reconhecível entre os personagens de o Encontro marcado de Fernando Sabino, o romance, quase escrevo bíblia, que o meu grupinho gostaria de arremedar na vida e na literatura. Não se tinha notícia de Murilo escalando, assim como Fernando, Hélio Pellegrino, Otto Lara Resende e Paulo Mendes Campos, companheiros de geração literária, os arcos do viaduto de Santa Teresa. Nem tocando fogo em casa de família para ver beldades de camisola a sair esbaforidas, como fizeram 
Drummond e Pedro Nava certa madrugada dos anos 1920. Só tive a confirmação de que Murilo de fato existia quando encontrei, na biblioteca da Praça da Liberdade, um exemplar de $O$ exmágico, publicado em 1947.

Murilo Rubião, isto era certo, estava inteiramente desemparelhado na ficção brasileira - e mesmo na ficção continental, pois ainda não sobreviera o cacofônico boom da literatura latino-americana. Livros como Cem anos de solidão, com personagens capazes de, literalmente, voar, ainda não haviam sido escritos. Para desconforto dos críticos que amam organizar autores em times, não havia, na paisagem literária, algum escritor "tipo Murilo Rubião".

Em papel impresso e até em carne e osso, Murilo voltou à circulação em 1965, quando a Imprensa Oficial de Minas publicou Os dragões $e$ outros contos. Tinha quase 50 anos, mas aos desavisados poderia até dar impressão de ser um estreante. Bem poucos leitores, na verdade, tinham sabido até então avaliar devidamente a arte de Murilo, cujo nome aparecia, no máximo, entre muitíssimos, na vala comum do vasto etecetera da ficção nacional contemporânea. Nem mesmo as antenas agudíssimas de Mário de Andrade, com quem ele se correspondeu entre dezembro de 1939 e dezembro de 1944, souberam captá-lo de imediato. "Mário gostava do autor", me disse certa vez Murilo, sem sombra de ressentimento, "e fazia o possível para gostar da obra..."

Antonio Candido, sempre tão atento, leu Os dragões e outros contos e, numa carta ao autor, se penitenciou por não haver, dezoito anos antes, registrado condignamente a chegada de O ex-mágico. Foi mestre Candido o responsável 
por dar ao contista a devida visibilidade, ao recomendá-lo como objeto de estudo ao jovem professor Jorge Schwartz, que em 1971 buscava um tema para sua tese em Teoria Literária. Por essa via, o nome de Murilo chegou também ao editor Jiro Takahashi, da Ática, que procurava um ficcionista de qualidade para inaugurar coleção. Jiro foi a Belo Horizonte e propôs a Rubião lançar O Pirotécnico Zacarias com 30 mil exemplares. O escritor, que em 1947 tivera de pagar parte da edição de $O$ Ex-mágico, recusado antes por seis editoras, reagiu com incredulidade. Esse camarada está louco, pensou. Não estava - tanto assim que em poucos anos $O$ Pirotécnico batia nos $100 \mathrm{mil}$. Da quase total obscuridade, Murilo Rubião saltou para a berlinda literária. "Me assustei um pouquinho", admitia.

Bem antes disso, em 1966, o contista teve a ideia de criar um suplemento literário como encarte semanal do Minas Gerais, o diário oficial do Estado, do qual era funcionário, e onde até então lhe cabiam tarefas como redigir necrológios até de gente viva. Sob generalizado ceticismo do establishment das letras mineiras de então, Murilo pôs de pé uma publicação que não tardou a ressoar para além da província e que, mais de meio século depois, resistente a crises de variada natureza, da falta de recursos ao obscurantismo de administradores estaduais, milagrosamente sobrevive, hoje sob os bons cuidados do contista e romancista Jaime Prado Gouvêa e sua diminuta equipe.

O atual diretor do Suplemento Literário de Minas Gerais, aliás, vem a ser um dos muitos escritores jovens que Murilo Rubião teve a sabedoria e generosidade de acolher em torno da publicação. Formou-se ali não igrejinha, como tantas vezes acontece, mas uma federação não 
só de grupos dos mais diversos, como também de livres atiradores da literatura. Daí nasceu uma informal Geração Suplemento, da qual fizeram parte, além de Jaime Prado Gouvêa, escritores como Sérgio Sant'Anna, recentemente falecido, e Luiz Vilela.

Primeiro como colaborador, depois como editor assistente, no Suplemento tive o privilégio incomparável de conviver com Murilo Rubião, e se mais não aprendi não foi por falta sua. Lições de literatura e também de vida. Dele recebi atenções por certo imerecidas - entre elas, pedidos para ler e opinar sobre versões interminavelmente retocadas de seus contos, alguns deles escritos ou principiados antes de minha chegada ao mundo. O exemplo radical seria $O$ convidado, no qual 26 anos se passaram entre a primeira e a última linha, merecendo crônica de Paulo Mendes Campos, que o viu brotar.

Num misto de emoção e vergonha, me pesa a sem-cerimônia com que, frangote das letras, eu palpitava na escrita de Murilo Rubião, seguro de mim como nunca mais seria. Tenho hoje a idade que tinha ele ao morrer, e de muito tempo precisei para compreender e admirar a silenciosa persistência e o rigor implacável de um artista que em toda a vida não publicou mais que 51 contos, dos quais descartou uma dúzia e meia. Quantos autores mais prolíficos nos deixaram obra capaz de se manter em pé com a firmeza dos 33 contos de Murilo Rubião? 